DOI 10.18699/SBB-2020-55

\title{
Сравнение методов выделения высокомолекулярной ДНК из плодов растений для нанопорового секвенирования
}

\author{
Гладышева-Азгари М.В.*, Петрова К.О. \\ НИЦ «Курчатовский институт», Курчатовский иентр геномных исследований, Москва, Россия \\ *e-mail: marglader@gmail.com
}

Ключевые слова: выделение ДНК, плодовые культуры, СТАВ, GITC, Oxford Nanopore

Мотивация и цель: С возрастом органы растения накапливают метаболиты, которые соосаждаются с нуклеиновыми кислотами при экстракции, поэтому высокомолекулярную ДНК хорошего качества легче выделить из молодых свежесобранных образцов незапасающих тканей. Однако получение молодых листьев в качестве исходного материала иногда не представляется возможным. Протоколы выделения ДНК из тканей растений обычно видоспецифичны, адаптированы только для листьев или требуют большого количества исходного материала. Цель данной работы - выявление наиболее универсального метода получения высокомолекулярной растительной ДНК из зародышей плодовых культур.

Maтериальl и алгоритмы: Для получения ДНК были взяты плоды сортов персика («Красная Москва», «Ветеран»), инжира («Медовый»), яблони и винограда. Мы сравнили три различных протокола для экстракции растительной ДНК: CTAB-метод выделения ДНК, GITC-метод и метод выделения для нанопорового секвенирования. Оценка качества и количества выделенной ДНК произведена на спектрофотометре NanoDrop 1000 (Thermo Scientific) и флюориметре Qubit (Thermo Scientific). Молекулярный вес ДНК оценивался при помощи электрофореза в агарозном геле.

Результаты: При применении различных методов для экстракции ДНК из зародышей наших объектов мы получили низкие концентрации ДНК с высоким уровнем загрязненности другими органическими агентами, что может быть связано с избытком и разнообразием запасающих веществ в этих тканях. В некоторых случаях благодаря нескольким стадиям очистки и переосаждений удалось избавиться от большей части загрязнителей.

Заключение: Мы протестировали несколько основных методов выделения высококачественной ДНК из плодов различных представителей плодовых культур. Было показано, что для экстракции ДНК из плодов необходима дополнительная модификация этих методов с целью удаления растительных метаболитов, связывающихся с нуклеиновыми кислотами.

Источник финансирования: Работа выполнена в Курчатовском центре геномных исследований при поддержке Министерства науки и высшего образования РФ, грант № 075-15-2019-1659. 